\title{
Study of Building Façade in Fishing Industries
}

\author{
Luqman Nashirudin Nafiq, Satriya Wahyu Firmandhani \\ Department of Architecture, Faculty of Engineering, Universitas Diponegoro, Indonesia \\ Corresponding e-mail: luqman77nafiq@gmail.com
}

Article info:

Received: 27-11-2021, Revised: 3-12-2021, Accepted: 3-12-2021

\begin{abstract}
Many industrial buildings are growing in Indonesia, one of them being the fishing industry. However, the industry has a monotonous and rigid facade. The facade is an essential element that makes the first impression. This study aims to evaluate how the facade of an ideal industrial building, especially in the fishing industry. The method used is descriptive qualitative on the several parameters of façade design. The results of the study are in the form of an evaluation and guidelines of the ideal facade, in terms of visuals, functions, and the requirements.
\end{abstract}

Keywords: Evaluation, descriptive qualitative, facade, fishing industry

\section{Background}

The sea area in Indonesia that can be managed is about 5.8 million $\mathrm{km}^{2}$, one of the growing industries is the fishing industry. With the emergence of many industrial buildings, it is worth noticed again about the facade or appearance. According to (Sinarwastu, 2016), a structure's characteristics that arise from the shape of the design or facade will form visitors' perceptions. Generally, office buildings or showrooms are located in front of the highlighted (Sudiyanto, 1997). The facade not only becomes a visual character but affects the quality and lighting in the building, Therefore, the facade in industrial buildings is quite essential. According to (Mihaljevic, 2009), natural light that enters a building can reduce the electrical energy used. But industrial facilities need to be considered; not all places must have the same intense lighting, depending on the type of work or machinery (Sudiyanto, 1997). Many of the facades in industrial buildings are made just like that. Whereas the facade can provide more value, and improve the performance of the industrial production.

With the development of the industrial area, the problem is some incompatibility with the appearance of facade, energy use, and function. Therefore, the facade design is an essential element. Researchers used several parameters in evaluating the facade. Therefore, evaluation is needed to get an ideal facade. The terms are visuals, functions, and requirements. The facade is expected to be as efficient as possible and also has a visual does not seem monotonous. So that industrial buildings can have more values, such as increasing production work, being comfortable, and eye catching.

\section{Methods}

The methods used by researchers are descriptive qualitative methods. Analysis obtained by the source with triangulation techniques or a combination of data sets Steps that need to be taken in descriptive qualitative methods for research to achieve their goals, among others:

1. Do a literature review. A literature review is needed to find out the elements that affect the facade and requirements of industrial buildings. The study is used as a guideline or parameter used as an analysis. 
2. Data capture. The data collection method consists of 2 kind of datas as follow:

a. Primary data is data that can be obtained directly hammering the research subject. The data is used to answer the researcher's question. Supomo in (Purhantara, 2010). The primary data can be done by interview or direct observation.

b. Secondary data is data that has existed or been previously available. This data is statistical data or data that has been processed so that is ready to be used in a statistic. (Moehar, 2002).

3. Data analysis. The data that has been collected is then analyzed and compared with parameters that follow the literature review. Parameters in researching building facade studies in the fishing industry are lighting, airing and humidity (openings), entrance, shape and mass of buildings, colors, materials, vocal points/eye-catching, and rhythm patterns.

4. Conclusion. After being analyzed through the parameters that have been determined, we can conclude and evaluate whether the case study follows the theory that has been studied before and get the best facade.

\section{Discussion}

\subsection{Case Study}

\subsubsection{Dua Putra Makmur Limited Company}
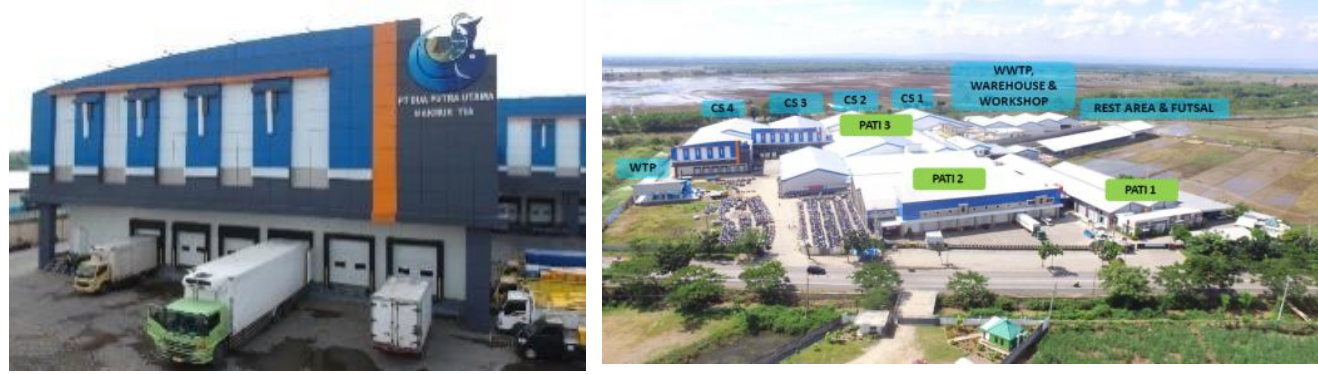

Figure 3.1 Dua Putra Makmur Tbk (https://duaputra.co.id/, 2021)

Dua Putra Utama Makmur (DPUM) is an integrated fisheries, marine products processing and cold storage company established in 2012. The industry is located in Pati, Central Java, Indonesia.

\subsubsection{Awindo International Limited Company}

Awindo International Limitide Company is a fishing industry that has been established since 2009. This industry is located at Jl. Cumi Raya No.7, Muara Baru Port, Penjaringan Village, Penjaringan Subdistrict, North Jakarta. 

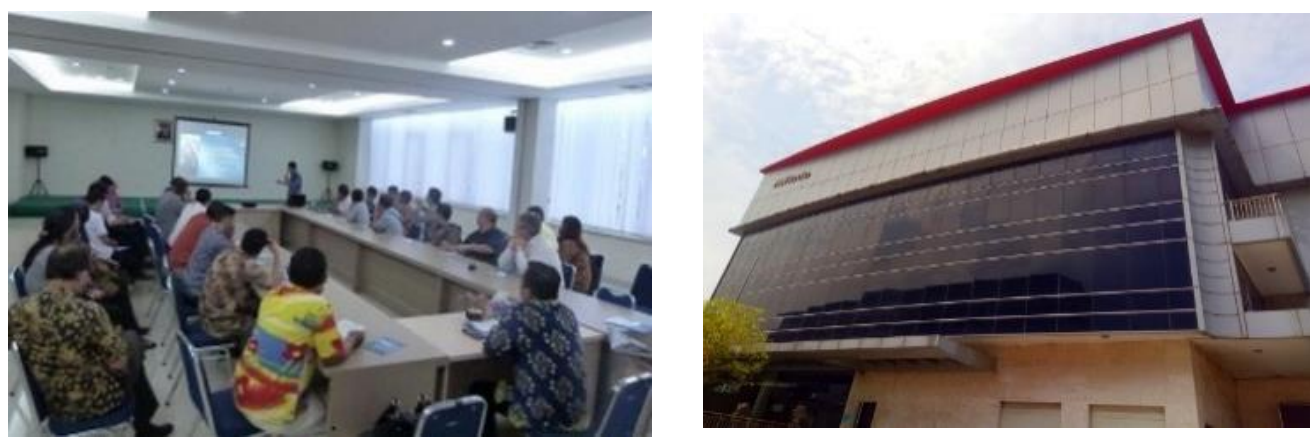

Figure 3.2 Awindo International

(https://www.awindointernational.com/, 2021)

\subsubsection{PT Bumi Menara Internusa}

PT. Bumi Menara Internusa was established in 1992 and began operations in 1992. This industry is located at Jl. Margomulyo 4e Tandes, Surabaya, East Java
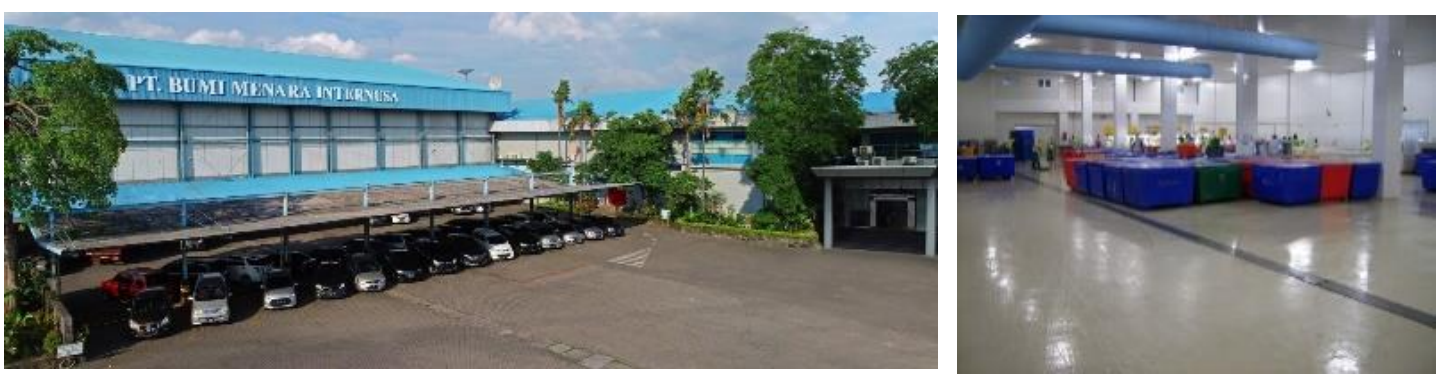

Figure 3.3 Bumi Menara Internusa

(https://www.ptbmi.com/, 2021)

The industry is all economic business activities that process raw materials and utilize all resources to produce products or goods with a higher value. In comparison, the fishing industry is all industrial activities related to the collection, breeding, processing, preservation, storage, transportation, marketing of fish and fish products. Types of fishing industries include fish farming, commercial fisheries, processing, producing fish products, and fish marketing (UK Essays, 2018).

Based on some of the above understandings, the fishing industry is all industrial activities including harvesting, breeding, processing, preservation, storage, transportation, and marketing that are processed to become higher-value goods.

\subsection{Facade Functions}

According to (Sastra, 2018) The facade has functions as a part of architectural work, there are:

1. Visual function. The facade has a role as a medium that gives the public a first impression of architectural work because it is the physical medium.

2. Inner Spatial Reflection Function. In the design process, the facade is the main element of architecture because the public will appreciate a building from its facade. 


\subsection{Facade Elements}

According to (Kosanti \& Dwiyanto, 2018) The facade has elements that need to be observed in the creation of the facade to be an excellent visual, there are :

a. Entrance. When we enter a building, we will pass through the entrance that becomes the transition from outside the establishment (public) into the building (private).

b. Ground Floor. The ground floor is a somewhat important element. The ground floor connects or transitions with the ground.

c. Openings. This element can be an exciting thing from a facade. Openings can be windows, doors, BV. This element plays a role so that users can see outside the room.

d. Signs and Ornaments. The sign is that everything installed by the company or others can be made separate from the building or fused with the installation. This element is functional as a form of visual communication.

e. Color. Colour becomes an essential part of the facade of the building because it will create a perception and impression of the public who sees the building. Harmonious colour combination by accentuating colours that are close to each other

f. Material. Applying material to the facade will create a point of interest so that the building becomes more attractive. For example, we use glass and wood; the atmosphere will be warmer and more familiar.

g. Tone or Vocal Point. According to (Adi et al., 2018), the vocal point is exciting and can steal the attention of observers with all the elements in it. In the vocal point, there are elements, namely textures (consisting of smooth or coarse surfaces) and the tone or dark light colour gives an atmosphere depending on what type of building.

In addition, to evaluate and study the facade, visual components that are objects of modification and transformation can be observed by making a classification of principles (Ching, 1984),these principles include:

- Geometry, geometry applied to the facade that embodies the principle of geometry in the built environment, such as triangles, circles, squares, or irregular.

- Symmetry is an informative idea that makes the building balance.

- Depth contrast is an informative idea that pays attention to the colour and lighting of the light-dark depth of a facade.

- Rhythm is a picture of a building component with good reps, both small and large scale.

- Proportion is a comparison between elements on a facade. There are limits in determining proportions: the shape, nature of materials, structural functions, or production processes.

- Scale is a comparison between some aspects of human size. Scale is the proportion used in determining the size and dimension of the facade element

\subsection{Lighting Review}

Industrial buildings require natural lighting and artificial lighting. There are several things to consider in designing lighting in industrial facilities, namely the use of natural light as much as possible, the level of criticality of light needs in industrial buildings, the type of work and activities, work time, structure, evenly distributed or not the need for light. Lamp colour requirements. Contrast or level of brightness.

According to the Regulation of the Minister of Health of the Republic of Indonesia Number 70 of 2016 on Standards and Requirements of Industrial Occupational Environment Health. Each 
room in the industry has different requirements, namely washing process, barrel filling, cleaning (200 lux), product washing, milling, cleaning, packaging (300 lux), finished eating, activities in the kitchen, product control, trimming, sorting, laboratory, cutting (500 lux), and inspection (1000lux). It is for areas outside of production, namely: areas that are rarely used. Activities or activities require minimal visual acuity, and pedestrians (average 5 lux); areas that are ordinary or somewhat routine and need low to moderate visual sensitivity (10 lux); area used several times, visual acuity (20 lux); Busy moving areas or activities of high visual acuity (50 lux); area to see details (100 lux); and the space used sees excellent details (200 lux).

\subsection{Air and Humidity Review}

High temperatures make the durability and comfort of work will be disturbed. It will affect the effectiveness and productivity of labour. Therefore, it should be considered that the air conditioning and humidity in industrial buildings is good.

According to (Indonesian National Standard, 2001) ventilation requirements consist of permanent openings that are windows, doors, or others that air can enter. The number of vents is not less than 5\%. According to the Regulation of the Minister of Marine Affairs and Fisheries of the Republic of Indonesia Number 17/Permen-Kp/2019 on The Requirements and Procedures for issuing Certificates of Processing Feasibility, for temperature issues in the fishing industry, in addition to industrial building storage rooms using an average temperature of $20^{\circ} \mathrm{C}-27^{\circ} \mathrm{C}$, for storage, freezing storage of temperatures around $-18{ }^{\circ} \mathrm{C}$, new storage of 0 $\stackrel{\circ}{ } \mathrm{C}$, and pasteurization products of $5 \stackrel{\circ}{\circ}$.

\subsection{Parameters}

The study of the theory is then compared with the data in the field based on predetermined parameters.

\subsubsection{Lighting}

Lighting at PT Dua Putra Makmur Tbk all uses artificial lighting. The facades all use solid fields, so no natural light enters the building. Artificial lighting is used for production rooms and areas outside the production, namely the manager's office. Although with the artificial lighting, the lighting requirements at PT Dua Putra Makmur have been met. Areas that may be given lighting are supporting areas of the building and the management room to reduce energy use even though it is not significant.

PT Awindo International has a wide enough opening by using glass material on its facade so that natural light can enter sufficiently. The area that gets natural light is the managing area. Lighting requirements meet the standards. According to reports, the weighing room has a light of 200 lux, while the managing site has the lighting of 300 lux that meets the requirements.

PT Bumi Menara Internusa facade uses polycarbonate material so that natural light from the sun can enter partly. Polycarbonate material makes the lighting in the building enough. The area that uses natural light is the area outside the production area. The lighting level of natural light is enough.

\subsubsection{Airing and Humidity (Aperture)}

At PT Bumi Menara Internusa, air conditioning and humidity are still felt less because the fulfilment of $5 \%$ of the floor area has not been implemented. The building has no opening elements to drain natural air. However, with artificial cooling, the entire space at PT Dua 
Makmur Internusa already meets temperature standards. (Regular reports of production standards).

At PT Awindo International, the air conditioning still does not get enough ventilation, and most of the air conditioning still uses artificial air conditioning. For the requirements of each temperature in each industrial building, PT Awindo International, based on weekly reports on technical including temperature, has been fulfilled. Because PT Awindo International checks or regular checks about it. Here is information from the temperature of the room at PT Awindo International

At PT Bumi Menara Internusa for its service is found in some production areas that utilize natural conditioning. With ventilation using insect retaining wire so that insects or dust can be minimized to enter. But some areas use artificial activity because some of these areas have minimal requirements of temperature. So to meet the temperature using artificial air conditioning.

\subsubsection{Entrance}

Pt Dua Putra Makmur Tbk industi building has several building masses. So, access from industrial buildings also has some access. For access to the production, the area has met the standards set, equipped with a laundry area and a dressing room. In addition, the material from the door has also been fulfilled.

But the entrance should be equipped with a sign. According to Willems and Ransch (1969), the character would give the director an opening to guide visitors.

Pt Awindo International has an entrance in front of the building. Access to the management room and production area is at the front of the building. According to (Faroga, 2014), the entrance location must represent the achievement and can reach or relate to any activity in the building. Then between the manager's section to the production section, there is another door that is the entrance of the production area. According to a technical report from PT Awindo International, the door is equipped with a washing area and various industrial building requirements.

At PT Bumi Menara Internusa has an entrance that is a building that is on the side. With handwashing. The material from the door meets the entrance requirements also close to the parking area so that access becomes easy.

\subsubsection{Mass Shape of Building}

Pt Dua Putra Makmur Tbk industry building has a rectangular mass shape. This mass is often used in industrial facilities. Industrial buildings can be processed into some more exciting masses, not only can be a place to produce goods and provide new experiences, as visitors and working in the industry. According to (Shirvani, 1985), the physical form of the mass of the building comes from a specific setting, namely height, retreat, closure, which is then combined.

At PT Awindo International has a mass of buildings in the form of boxes or squares, but given a game back and forth (depth contrast) so that it is not too flat. But there needs to be an increase in mass or a more attractive form in the management area to be more attractive.

At PT Bumi Menara Internusa also has a box or rectangular mass, the most common form of mass used in industrial buildings in Indonesia. However, it is felt that mass structure needs to be more varied with the play of the amount of mass. 


\subsubsection{Color}

At PT Dua Putra Makmur Tbk has a blend of colours that are not monotonous because it does not use one colour only. The paint on the facade has a dominant blue colour combined with white and slightly orange. The blue colour represents the function in it, which makes an impression and reflects the tasks that are in it. The colouring is dominant with aluminium composite panel (ACP), so that the durability and durability of the colour are pretty good. Blue, which is a medium colour, reflects $20-50 \%$ light.

At PT Awindo International has a combination of pretty exciting colours. The dominant colour used is the grey colour that comes from the cladding, with the horizontal elements at the top being red. This colour alloy is quite good because it will provide its appeal. According to (Nugraha, 2016) the colour red has an expansive, dominant, active and vital impression. They were then combined with the colour of black glass, making industrial buildings more modern. The walls at the bottom use a beige colour.

At PT Bumi Menara Internusa, the colour used is quite good. The almost dominant blue blend is like PT Dua Putra Putra Tbk because it also reflects the fishing industry. The blue colour is combined with the colour polycarbonate in white, which will emit the colour of lights that come from inside at night.

\subsubsection{Material}

Pt Dua Putra Makmur Tbk's industry building is predominantly facade material using ACP material cladding (Aluminum Composite PanelMaterial is quite durable and does not require much maintenance. The material also meets the requirements of industrial buildings. With colour games that characterize the buildings of the fishing industry. In addition to the facade of the ACP also the facade consists of plaster bricks

Pt Awindo International has a reasonably diverse material. The front is used for the manager's office so that the facade on the show is predominantly glass material. So, with this material becomes more modern. According to (Alfari, 2017), glass material will make the building seem more modern. At the same time, other materials used on the facade are metal cladding panels. Material cladding panels because it is easy to maintain. As for the wall at the bottom, only the plaster wall finish paint. The materials also meet the requirements of industrial buildings.

PT Bumi Menara Internusa has a facade material with polycarbonate material, so light can still enter but not much. And at night, it will emit light from the lamp so that it becomes a different ambience. The roof uses a PVC roof that continues to the facade. However, the treatment of polycarbonate itself is quite a lot, and polycarbonate material can peel off or be less durable.

\subsubsection{Vocal Point/ Eye Cathing}

PT Dua Putra Utama Tbk eye-catching comes from the material elements of ACP cladding, with a game of depth contrast. The blue colour also attracts the eye of observers. But it still feels lacking and still seems ordinary.

At PT Bumi Menara Internusa has eyecatching with black glass material because the colour on the surrounding material is neutral so that contrast occurs and can be more attractive glass. But it still seems ordinary. There needs to be a more varied game.

At PT Bumi Menara Internusa does not have eyecatching because there is a difference between material and colour. Everything seems monotonous, and the absence of elements that attract eye focus. 


\subsubsection{Patterns and Rhythms}

This industrial building of PT Dua Makmur Tbk has a rectangular pattern on the facade formed from panel cladding. In addition, there is also a pattern of repetition or repetition in the vertical design of the cladding. Repetition can give a dynamic impression. According to (Frie, 2013), if fewer and fewer repetitions of the scale size, the item becomes monotonous.

Pt Awindo International industrial building has the same pattern as PT Dua Putra Makmur Tbk, a rectangular design that comes from cladding materials. In the glass, there is a repeating horizontal pattern. Then the shape of the facade of the building has an asymmetrical shape.

The industrial building PT Bumi Menara Internusa makes a pattern derived from steel structures, which simultaneously become vertical elements of the facade. Sheer details are also found in the undulating texture of PVC. The similarity in terms of alignment with the mass of the building is good enough.

\section{Conclusion}

In evaluating the facade of the fishing industries building, several elements are used as parameters. Therefore, an evaluation of the facade could be conducted and get the perfect facade. From the sample of the buildings can be concluded, namely:

\section{a. Lighting}

Lighting in the fishing industry does not require to use of natural light. Lighting that must be consistent and vary according to its requirements make artificial lighting a solution. However, it can be given openings or void elements on the manager or support spaces, to get natural lighting to reduce energy use.

\section{b. Airing and Humidity (Aperture)}

There are temperature requirements for each room that must be met. With some spaces, can use natural conditioning. Natural air conditioning will be better because it can reduce energy use or can use exhaust fans. What needs to be considered about the place of space and barriers so that insects cannot enter.

\section{c. Entrance}

It is necessary to pay attention to the affordability of the entrance for all spaces. In addition, it must still meet the entry requirements of industrial buildings both from materials and facilities.

\section{d. Mass Shape of Building}

The mass form of industrial buildings does not demand attractive conditions, but production efficiency is essential. The shape of the mass can be more interesting overcome by adding enough mass to get variety. The manager or supporting area can use a varied or attractive mass form.

\section{e. Colour}

The colour must remain solid and pay attention to the reflection of light produced from the paint. Colour in industrial buildings need to be considered about their durability with minimal maintenance.

\section{f. Material}

The material in all three buildings is quite good concerning the requirements, especially from durability and maintenance. But more varied materials are needed to attract the eyes. 


\section{g. Vocal Point or Eye Catching}

Vocal points are needed so that the building does not seem monotonous and rigid. Vocal points can use color material to their structure because the industry can also be a medium of learning and recreation that can increase sales of these products.

\section{h. Patterns and Rhythms}

There needs to be more variation in pattern play for the facade. These patterns can be formed from material variations to structure.

\section{References}

Adi, I. W., Yasa, P., Artayasa, I. N., \& Raharja, I. G. M. (2018). Konsep Dan Prinsip Focal Point Pada Desain Game D 'Kala. 22(1), 1-12.

Alfari. (2017). Kaca Sebagai Bahan Bangunan. Retrieved from Kaca Sebagai Bahan Bangunan. https://www.arsitag.com/article/kaca-sebagai-bahan-bangunan

Alfian, R. (2017). Persepsi Pengunjung terhadap Fasad Mall Gandaria City. http://www.academia.edu/30039176/persepsi_pengunjung_terhadap_fasad_mall_ganda ria_city

BPS, - S. I. (2019). Badan statistik. https://www.bps.go.id/subject/56/perikanan.html\#subjekViewTab3

Ching, D. K. F. (1984). Arsitektur: Bentuk, Ruang dan Susunannya.

Faroga, R. (2014). Perletakan dan Bentuk Desain Main Entrance Pada Bangunan Mal Terbuka. E-Journal Graduate Unpar, 1(1), 1-10.

Frie, J. (2013). KomposisiPada Fasade Bangunan.

Kosanti, A. I., \& Dwiyanto, A. (2018). Kajian Terhadap Fasad Mall Di Semarang. Modul, 18(2), 101. https://doi.org/10.14710/mdl.18.2.2018.101-107

Mihaljevic, J. . H. L. . \& L. E. (2009). Daylight metrics and energy savings. Lighting Research \& Technology.

Moehar, D. (2002). Metode Penelitian Sosial Ekonomi: Dilengkapi beberapa alat analisa dan penuntun penggunaan. https://onesearch.id/Record/IOS3239.slims-33696

Peraturan Menteri Kelautan dan Perikanan Republik Indonesia Nomer 1 Tahun 2020 tentang Petunjuk Teknis Pengelolaan Dana Alokasi Khusus Fisik Bidang Kelautan dan Perikanan Tahun 2020. April, 5-24.

Peraturan Menteri Kelautan Dan Perikanan Republik Indonesia Nomor 6/Permen-Kp/2018 Tentang Keselamatan Dan Kesehatan Kerja Di Lingkungan Kementerian Kelautan Dan Perikanan. 109.

Peraturan Menteri Kelautan dan Perikanan Nomer 17 Tahun 2019 tentang Persyaratan dan Tata Cara Penerbitan Sertifikat Kelayakan Pengolahan. Fisheries, 1-101.

Peraturan Menteri Kesehatan Republik Indonesia Nomer 70 Tahun 2016 tentang Standar dan Persyaratan Kesehatan Lingkungan Kerja Industri. May, 31-48.

PT. Awindo International. (2018). Lampiran Laporan PT. Awindo International.

Pt Dua Putra Makmur Tbk Public Expose. 3, 103-111.

Purhantara. (2010). Metode Penelitian Kualitatif untuk Bisnis. Graha IImu. https://opac. perpusnas.go.id/DetailOpac.aspx?id=437706

Sandy, I. M. (1985). Republik Indonesia geografi regional : buku teks / I Made Sandy. Jurusan Geografi, $\quad$ FMIPA, Universitas 1985. https://opac. perpusnas.go.id/DetailOpac.aspx?id=836887\#

Sastra, S. (2018). Inspirasi Fasad Rumah Tinggal. Journal Universitas Atma Jaya, 53(9), 1689-1699.

Shirvani, H. (1985). The Urban Design Process. Van Nostrand Reinhold Company. 
Sinarwastu, A. K. E. (2016). Landasan Konseptual Perencanaan dan Perancangan Pusat Perbelanjaan di Surabaya dengan Pendekatan Arsitektur Hijau [UAJY]. https://e-

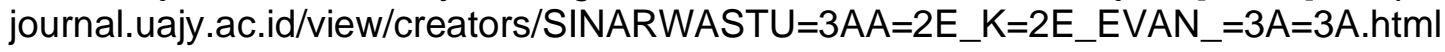

Standar Nasional Indonesia. (2001). Sni 03 - 6572 - 2001. Tata Cara Perancangan Sistem Ventilasi Dan Pengkondisian Udara Pada Bangunan Gedung, 1-55.

Sudiyanto, S. (1997). Industri Pengalengan Ikan di Cilacap.

UK, E. (2018). The Seven Unique Features Of E-Commerce Essay. https://www.ukessays.com/essays/informationtechnology/the-seven-unique-features-ofe-commerce-essay.php?vref=1 